\title{
Phytoremediation and Biosorption Potential of Lythrum salicaria L. for Nickel Removal from Aqueous Solutions
}

\author{
Nüket Akanıl Bingöl ${ }^{1}$, Ferda Özmal ${ }^{2}$, Betül Akın ${ }^{1 *}$ \\ 'Department of Biology, Dumlupinar University, Kutahya, Turkey 43100 \\ ${ }^{2}$ Department of Biochemistry, Dumlupinar University, Kutahya, Turkey 43100
}

Received: 11 April 2017

Accepted: 22 April 2017

\begin{abstract}
Pollution of water sources with heavy metals is one of the most important global environmental issues. Even though there are many physical and chemical methods for removing heavy metals from contaminated water, in recent years cost-effective and environmentally friendly techniques such as phytoremediation and biosorption are used to remove heavy metals from water. In this study, phytoremediation and biosorption potential of Lythrum salicaria L. for nickel removal from aqueous solutions were investigated. Phytoremediation experiments were conducted at 10\% Hoagland solution with $0,10,15,20,25$, 50, and $100 \mathrm{mg} / \mathrm{L}$ nickel, and $\mathrm{pH}$ levels of 5, 6, and 7 to determine the accumulation of nickel in vegetative parts of L. salicaria. Phytoremediation results indicated that maximum Ni (II) accumulation by L. salicaria was at pH 7 with $10 \mathrm{mg} \mathrm{Ni} / \mathrm{L}$ and distribution of $\mathrm{Ni}$ (II) was in the root $(3,737.8 \mathrm{mg} / \mathrm{kg} \mathrm{DW})>$ shoot $(697 \mathrm{mg} / \mathrm{kg}$ DW) $>$ leaf (418.4 mg/kg DW) of L. salicaria. On the other hand, the effect of $\mathrm{pH}$, biomass dosage, contact time, and initial $\mathrm{Ni}$ (II) concentration on the biosorption potential of L. salicaria roots was investigated in a batch system at room temperature. Optimum conditions were achieved at $\mathrm{pH} 7$ with the biomass dosage of $6 \mathrm{~g} / \mathrm{L}$ at an equilibrium contact time of $40 \mathrm{~min}$. Equilibrium data was adapted to Langmuir and Freundlich isotherm models to find the best-fitting model. The Langmuir isotherm model described the biosorption process best with a maximum monolayer sorption capacity of $9.1580 \mathrm{mg} / \mathrm{g}$ for $\mathrm{Ni}$ (II) ions.
\end{abstract}

Keywords: hydroponic culture, Lythrum salicaria, nickel pollution, phytoremediation

\section{Introduction}

Heavy metal pollution of freshwater is a serious issue worldwide, particularly in developing countries such as Turkey [1-4]. Natural and anthropogenic activities such as urban sewage, tanneries, and the textile industry have

*e-mail: betul.akin@dpu.edu.tr

contaminated fresh water with various metals, including $\mathrm{Zn}, \mathrm{As}, \mathrm{Pb}, \mathrm{Ni}, \mathrm{Cr}$, and $\mathrm{Cd}$ [5-6].

Heavy metals are non-biodegradable and therefore it is very important to remove them from the environment in terms of the health of living organisms. Some technologies - including ion exchange, reverse osmosis, electro dialysis, coagulation-precipitation, electrochemical operation, and filtration - have been used for their removal from aquatic systems [7-9]. Because most of these techniques mentioned above are costly, economical, and 
environmentally friendly, techniques such as biosorption and phytoremediation have been used to remove heavy metals from aquatic environments in recent years [10-12]. Biosorption is known as a metabolically passive process. There is no danger of toxicity of sorbent by sorbate solution. Heavy metal removal mechanism by this process depends on the adsorption of metals onto the surface of dead cells, and the rate of the process is very quick and reversible. On the other hand, phytoremediation technique remediates contaminated water by using hydroponically cultivated plants. Both of the methods are originated on biological materials; while the biomass in biosorption is not alive, living cells are used in phytoremediation [1314]. Wetland plants that showed high biomass are mostly used to remove heavy metals from aquatic systems such as water hyacinths, water lettuce, and cattail [15].

Under the present investigation, Lythrum salicaria L. was used to determine its potential in removing nickel from aquatic systems. The geographic origin of $L$. salicaria (Lythraceae) is Eurasia. It is the most common aquatic plant in Turkey and shows a distribution along rivers, lakes, and canals. L. salicaria is a herbaceous perennial plant that grows up to $20-180 \mathrm{~cm}$ tall along the wetlands between $0-1,400 \mathrm{~m}$ altitude. The color of flowers is red to purple with 6-12 petals and 12 stamens and they appear from July to September. Fruit is capsule. A single mature plant can produce 2-3 million seeds per year [1617]. The Lythrum generic name comes from Greek Word "luthron," or blood, referring to its ability to stop bleeding. The main compounds of the plant are tannins, flovans, and anthocyanins. L. salicaria is used medicinally to treat diarrhea, varicose veins, hemorrhoids, bleeding gums, and eczema [18-20].

One of the heavy metals that has reached high levels dangerous for human beings and aquatic organisms is nickel (Ni). Ni (II), one of its toxic elements, is widely distributed in aquatic systems. The origins of $\mathrm{Ni}$ (II) contamination in the environment are metal mining, glass industry, fossil fuel burning, industrial wastes, fertilizers, and vehicle emissions [21-22]. Human exposure to nickel over $0.04 \mathrm{mg} / \mathrm{L}$ in consumption water causes allergies in the form of contact dermatitis, lung fibrosis, cardiovascular and kidney diseases, and lung and nasal cancers [23-24]. In this study we tested the biosorption and phytoremediation potential of L. salicaria for nickel removal from aquatic systems.

\section{Material and Methods}

\section{Phytoremediation Experiment}

Seeds of $L$. salicaria were randomly collected during September to October 2015 from populations along the Porsuk River, Kütahya $\left(39^{\circ} 25^{\prime} \mathrm{N}\right.$ and $\left.29^{\circ} 58^{\prime} \mathrm{E}\right)$, where the plant showed optimum distribution (Fig. 1). The seeds were sewn into pots filled with soil and placed in pools filled with water in the greenhouse. The plants were grown in this condition until we had about $10 \mathrm{~cm}$-high seedlings.

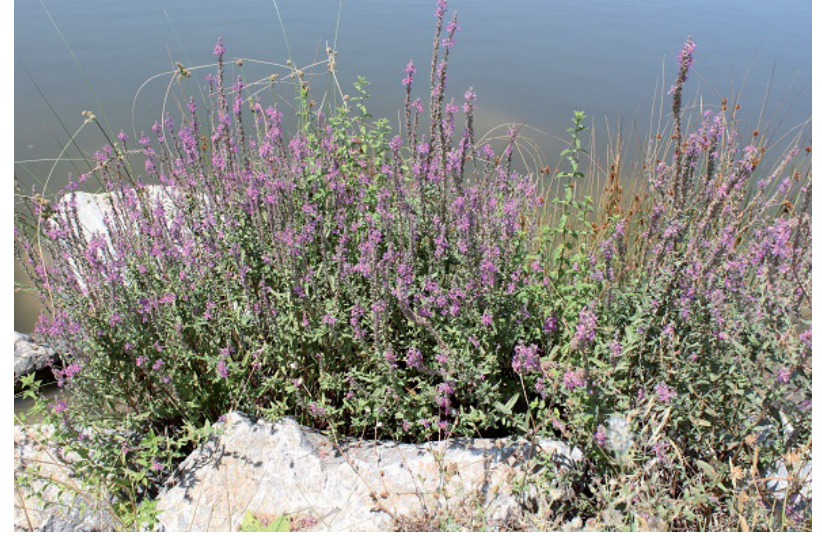

Fig. 1. Lytrum salicaria population along the Porsuk River (Kütahya).

For acclimatization, seedlings were trans-ferred to hydroponic culture containing 10\% Hoagland for 15 days.

Experiments were performed in pots (2.5 L capacity) of hydroponic culture system. The study had three steps. After adaptation, in the first step L. salicaria seedlings were treated with $10 \%$ Hoagland solution with eight different $\mathrm{Ni}$ (II) concentrations, prepared by using $\mathrm{NiCl}_{2} \cdot 6 \mathrm{H}_{2} \mathrm{O}$ $(0,5,10,15,20,25,50$, and $100 \mathrm{mg} \mathrm{Ni} / \mathrm{L})$ for seven days to determine the maximum $\mathrm{Ni}$ (II) concentration that plants accumulate. In the second step, L. salicaria seedlings were treated to $10 \%$ Hoagland solution containing $10 \mathrm{mg} / \mathrm{L} \mathrm{Ni}$ (II) at three different pH levels (5, 6, and 7). In the last step, L. salicaria seedlings were treated to $10 \%$ Hoagland solution containing $10 \mathrm{mg} / \mathrm{L} \mathrm{Ni}$ (II) to determine the accumulation of $\mathrm{Ni}$ (II) in vegetative parts of the plant (root, shoot, and leaf). In the first and second steps of the experiment, the roots of seedlings were washed with $1 \%$ Na-EDTA and ultra-pure water. Then the whole seedlings were dried at $70^{\circ} \mathrm{C}$ for 48 hours. In the last step, the same processing was followed as mentioned above, but instead of using whole seedlings, the roots, shoots, and leaves of the L. salicaria were separated, dried, and ground to prepare samples for digestion. $0.1 \mathrm{~g}$ plant sample was digested by wet digestion method based on nitric acid and hydrogen peroxide [25].

\section{Biosorption Experiment}

Dried roots of $L$. salicaria were used as biomass for the biosorption of Ni (II) ions. Firstly, dried roots were washed with deionized water and then dried at $80^{\circ} \mathrm{C}$. Then the dried biomass was ground to a particle size of $300 \mu \mathrm{m}$ and stored in a desiccator for further use. A stock solution of $\mathrm{Ni}$ (II) was prepared using $\mathrm{NiCl}_{2} \cdot 6 \mathrm{H}_{2} \mathrm{O}$. The working solutions were prepared by the appropriate dilutions from the stock solution. All the experiments were performed at room temperature. $\mathrm{pH}$ of the solutions were adjusted by $\mathrm{HCl}$ or $\mathrm{NaOH}$. Biosorption experiments were carried out at different $\mathrm{pH}$ values. $0.1 \mathrm{~g}$ of dried biomass was immersed in $50 \mathrm{~mL}$ of $100 \mathrm{mg} / \mathrm{L} \mathrm{Ni}$ (II) solution and $\mathrm{pH}$ of the solutions were adjusted from 1 to 7 and agitated at 
a constant speed for an hour. The effect of biomass dosage was controlled by ranging the amount of samples from 0.5 to $10 \mathrm{~g} / \mathrm{L}$ at the determined $\mathrm{pH}$. Then the effect of contact time was investigated at various time intervals between 5 and 120 minutes at the constant $\mathrm{pH}$ and biomass dosage. And lastly the effect of initial concentration was studied. The concentrations of $\mathrm{Ni}$ (II) solutions varied between the ranges of $2.5-100 \mathrm{mg} / \mathrm{L}$ while the other parameters were stable at the determined conditions. After the batch experiments were completed, the solutions were centrifuged.

$\mathrm{Ni}$ (II) concentration of plant samples from biosorption and phytoremediation experiments were analyzed using an atomic absorption spectrometer (Analytikjena ContrAA 300) at Dumlupinar University, Advanced Technologies in Design, Research and Development and Application Centre.

\section{Data Analysis}

Data were analyzed using the JMP 6 SAS [26] program. F-test was used to determine the differences between the applications at $\mathrm{p}<0.05$ level. TUKEY-HSD multiple comparison test was used on applications that were statistically different according to the F-test.

\section{Results and Discussion}

\section{Phytoremediation Experiment}

Ni (II) can cause toxic effects in plants over certain concentrations (11.74 ppm), such as chlorosis, necrosis, and retardation of germination, inhibition of growth, and reduction of yield [21]. Also, Singh and Pandey [27] reported that $\mathrm{Ni}$ induced visible toxicity symptoms in water lettuce subjected to exposure of higher concentrations (1.0 and $10.0 \mathrm{ppm}$ ), and maximum reduction in chlorophyll and protein content was observed at $10 \mathrm{ppm} \mathrm{Ni}$. On the other hand, Chen et al. [21] and Chami et al. [28] indicated that $15,20,25,50$, and $100 \mathrm{mg} \mathrm{Ni} / \mathrm{L}$ solutions caused death of the above- and below-ground parts of all seedlings. In this study, results of the first step of the experiment showed that maximum Ni (II) accumulation by L. salicaria was obtained in solutions containing 5 and $10 \mathrm{mg} \mathrm{Ni} / \mathrm{L}$, and solutions containing $15,20,25,50$, and $100 \mathrm{mg} \mathrm{Ni} / \mathrm{L}$ caused death of the above- and below-ground parts of all L. salicaria seedlings. Ni (II) accumulation at concentrations of 5 and $10 \mathrm{mg} \mathrm{Ni} / \mathrm{L}$ in L. salicaria were 2,582 and $5,523.2 \mathrm{mg} / \mathrm{kg}$ DW (dry weight), respectively (Fig. 2a). Thus, Ni accumulation in the whole plant increased with increasing nickel concentrations up to $10 \mathrm{mg} \mathrm{Ni} / \mathrm{L}$.
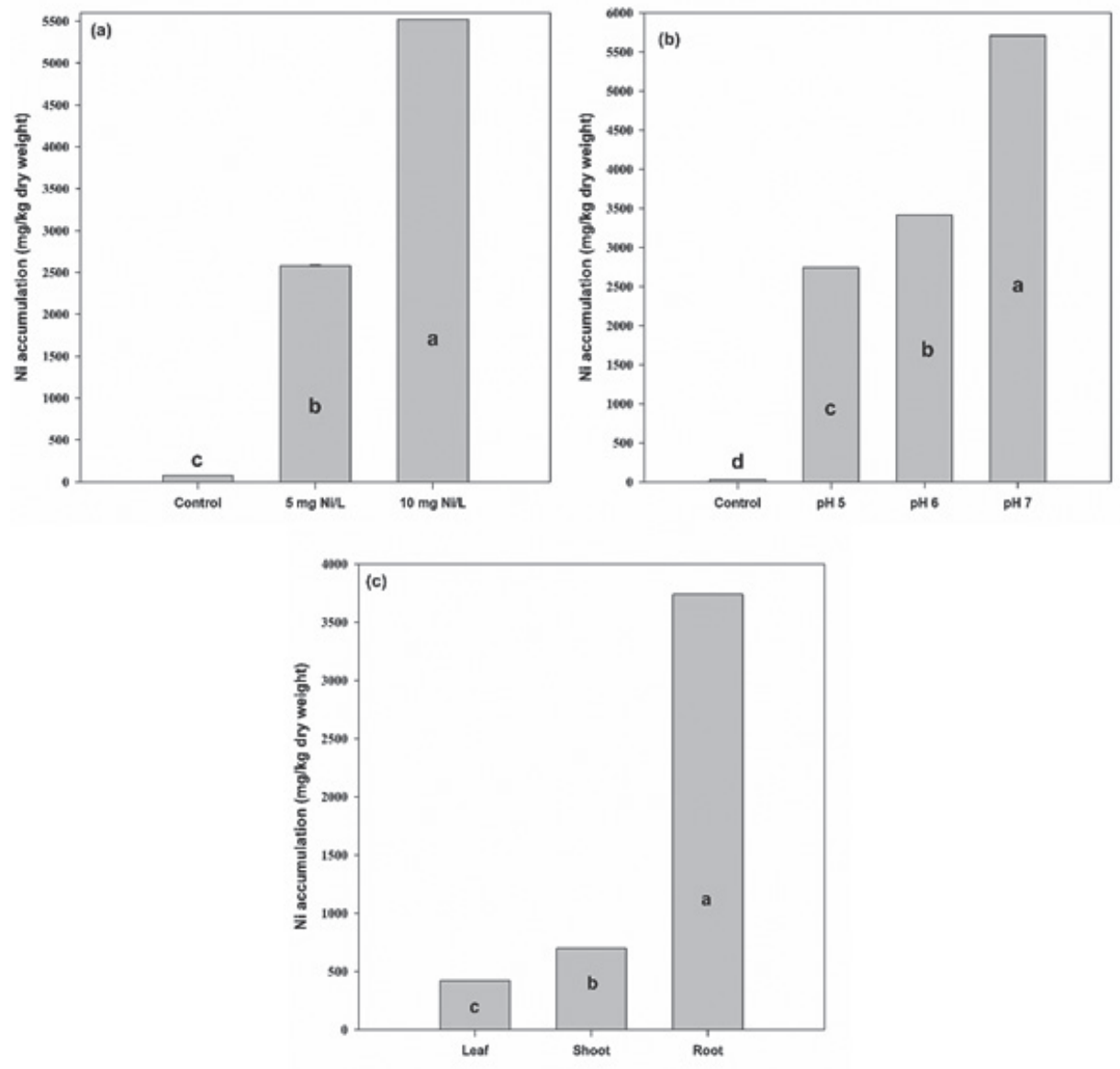

Fig. 2. The accumulation of $\mathrm{Ni}$ (II) (mg/kg dry weight) in L. salicaria; a) different concentrations of $\mathrm{Ni}$ (II) (Control, $5 \mathrm{and} 10 \mathrm{mg} \mathrm{Ni} / \mathrm{L}$ ) $(\mathrm{F}=106,442.5 ; \mathrm{p}<0.05), \mathrm{b})$ different $\mathrm{pH}$ levels $(\mathrm{F}=714,909.5 ; \mathrm{p}<0.05)$ and $\mathrm{c}) \mathrm{Ni}$ (II) accumulation in different organs of $L$. salicaria at $\mathrm{pH} 7$ with $10 \mathrm{mg} \mathrm{Ni} / \mathrm{L}(\mathrm{F}=166,367.5$; $\mathrm{p}<0.05)$. 
Changes in the physiochemical conditions of the aquatic environment such as $\mathrm{pH}$, redox potential, organic ligands and temperature have impacts on proportion of the metal ions that plants can accumulate [15]. The $\mathrm{pH}$ of the solution is the most important variable affecting accumulation capacity in nickel-contaminated water. According to Kaur et al. [29], the highest Ni accumulation by Lemna minor was determined at pH 6 and pH 7 . Kukier et al. [30] also stated that the accumulation of nickel by Alyssum increased with increasing $\mathrm{pH}$ in soil. Results of the second step of the experiment showed that $\mathrm{Ni}$ (II) accumulation at $10 \mathrm{mg} \mathrm{Ni} / \mathrm{L}$ by L. salicaria was significantly increased at higher $\mathrm{pH}$ values. While the lowest $\mathrm{Ni}$ (II) accumulation was obtained at $\mathrm{pH} 5$ (2739.5 mg/kg DW) and pH $6(3413.3 \mathrm{mg} / \mathrm{kg})$, the highest $\mathrm{Ni}$ (II) accumulation was obtained at pH $7(5708.3 \mathrm{mg} / \mathrm{kg}$ DW) in L. salicaria seedlings (Fig. 2b).

Analyses of Ni (II) in the roots, shoots, and leaves of L. salicaria, grown in $10 \mathrm{mg} \mathrm{Ni} / \mathrm{L}$ concentration, showed statistically significant differences (Fig. 2c). Results indicated that maximum $\mathrm{Ni}$ (II) accumulation was at $\mathrm{pH}$ 7 with $10 \mathrm{mg} \mathrm{Ni} / \mathrm{L}$, and the distribution of Ni (II) was in the root $(3737.8 \mathrm{mg} / \mathrm{kg} \mathrm{DW})>\operatorname{shoot}(697 \mathrm{mg} / \mathrm{kg} \mathrm{DW})>$ leaf (418.4 mg/kg DW) of L. salicaria, which showed that L. salicaria had great potential for phytoremediation of nickel in its root. According to our results, $77 \%$ of Ni (II) accumulation by L. salicaria was retained in the root of the plant. Recent studies indicated that aquatic fern Salvinia minima Baker also accumulated Ni more in roots than in leaves [31]. Yusuf et al. [32] and Vajpayee et al. [33] also reported that $\mathrm{Ni}$ accumulation was more pronounced in roots rather than the shoot in barley and maize, and aquatic plant Vallisneria spiralis L., respectively. Chen et al. [21] stated that over $50 \%$ of Ni (II) absorbed by the plants was retained in the roots of xylem parenchyma cell walls and vacuoles. When comparing its accumulation capacity and tolerance to $\mathrm{Ni}, L$. salicaria is a suitable plant to use in phytoremediation at the aquatic environments contaminated with Ni.

\section{Biosorption Experiments}

\section{Effect of $p H$}

In the biosorption process $\mathrm{pH}$ is known as the most significant parameter that depends on the competition between the metal ions and protons for the binding sites $[13,34]$. $\mathrm{pH}$ effect on the biosorption of $\mathrm{Ni}$ (II) ions onto L. salicaria biomass between the $\mathrm{pH}$ range of 1-7 was studied.

Fig. 3 clearly indicates that as $\mathrm{pH}$ of the solutions increases, uptake capacity of biomass increases. $\mathrm{pH} 7$ is the optimum $\mathrm{pH}$ for the biosorption of $\mathrm{Ni}$ (II) ions onto biomass. At lower $\mathrm{pH}$ values the binding sites on the surface of the biomass were about completely protonated and positively charged $\mathrm{Ni}$ (II) ions that were repulsed by protons. By increasing $\mathrm{pH}$, the surface of the biosorbent was more negatively charged and this resulted with the electrostatic interactions with $\mathrm{Ni}$ (II) ions [8, 35-36].

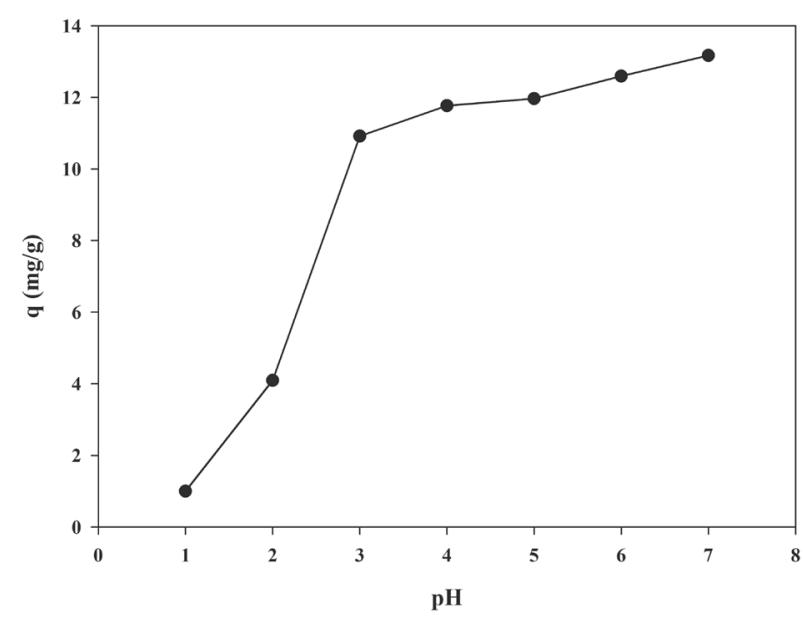

Fig. 3. Effect of $\mathrm{pH}$ on $\mathrm{Ni}$ (II) ions biosorption onto L. salicaria roots (Ni (II) concentration:100 mg/L, adsorbent dosage: $2 \mathrm{~g} / \mathrm{L}$ ).

Similar results have been reported by other researchers. Akar et al. [37] indicated that a precipitate occurs in the form of $\mathrm{Ni}(\mathrm{OH})_{2}$ at higher $\mathrm{pH}$ values greater than 8.3 in dilute solutions of $\mathrm{Ni}$ (II) ions and preferred to study at $\mathrm{pH}$ 6.5 (the original pH of $\mathrm{Ni}$ (II) solution). Hanif et al. [38] and Kaur et al. [29] also mentioned that at $\mathrm{pH}$ values lower than $6, \mathrm{Ni}$ (II) ion removal was partly inhibited due to the competition between hydrogen and Ni (II) ions onto the sorption sites.

\section{Effect of Biomass Dosage}

As can be seen from Fig. 4, varying the biomass dosage from 0.5 to $10 \mathrm{~g} / \mathrm{L}$ at $\mathrm{pH} 7$ and contact time of $60 \mathrm{~min}$. increases the percentage of $\mathrm{Ni}$ (II) removal from 18 to $65 \%$. The biosorption process reaches an equilibrium at a dosage of $6 \mathrm{~g} / \mathrm{L}$. A further increase doesn't change the uptake ratio. Therefore, $6 \mathrm{~g} / \mathrm{L}$ biomass dosage was selected as the optimum value for biosorption experiments. This result can be attributed to the saturation of binding sites

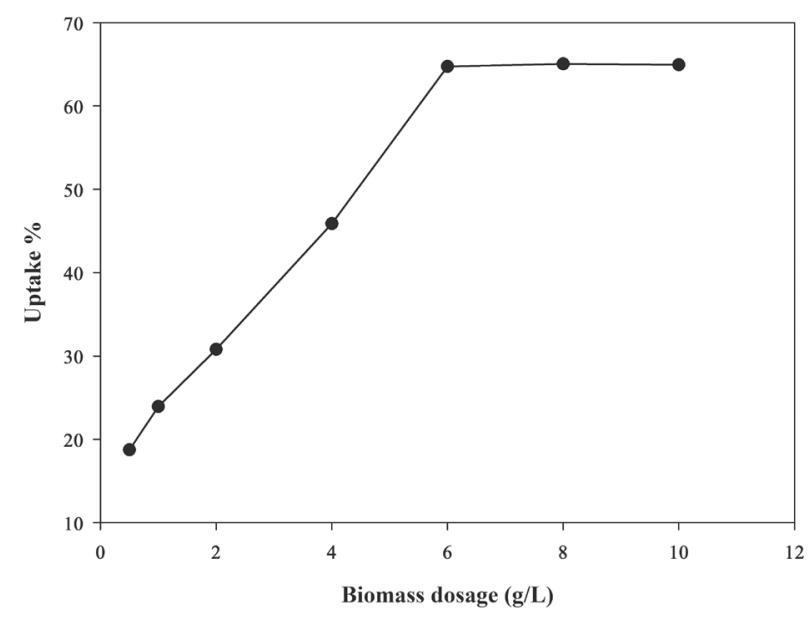

Fig. 4. Effect of biomass dosage on $\mathrm{Ni}$ (II) ions biosorption onto L. salicaria roots ( $\mathrm{Ni}$ (II) concentration:100 mg/L, pH: 7). 


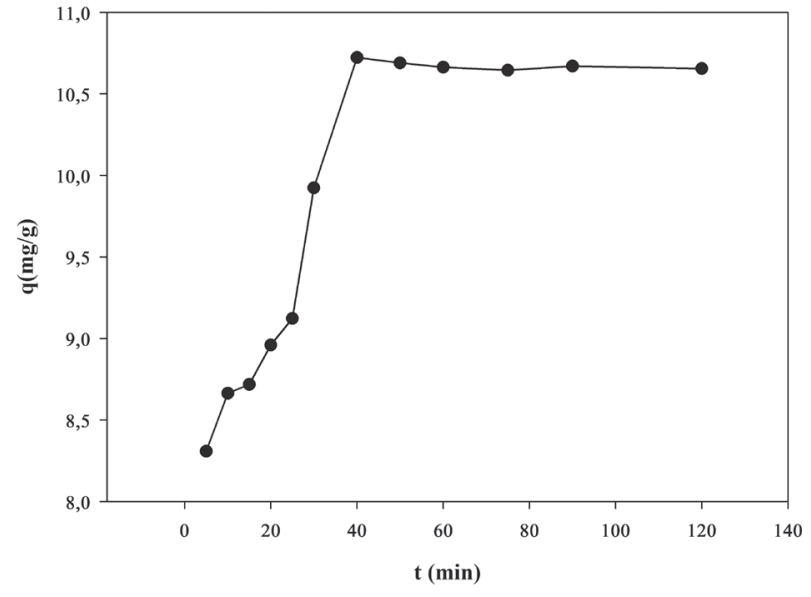

Fig. 5. The effect of contact time for Ni (II) ions biosorption onto L. salicaria roots (Ni (II) concentration:100 mg/L, pH:7, biomass dosage: $6 \mathrm{~g} / \mathrm{L}$ ).

with the Ni (II) ions [39]. Also, the partial aggregation that occurs at higher dosages decreases the active sites on the biomass. Experimental results of Sar1 et al. [8], Reddy et al. [40], and Fawzy et al. [41] are compatible with the literature. In these studies biosorption capacity increases to an equilibrium dosage and then tends to be almost the same.

\section{Effect of Contact Time}

In the biosorption of $\mathrm{Ni}$ (II) ions by L. salicaria roots, the effect of contact time was shown in Fig. 5. It can be seen that biosorption capacity increases with contact time up to $40 \mathrm{~min}$. After that point, extending the time does not have a positive influence on adsorption capacity. Therefore, further experiments were carried out at 40 $\min$. At the beginning of the biosorption process, there are many vacant active binding sites on the biomass surface. However, in the process of time, metal uptake of biomass decreases due to the gradual occupancy of the active binding sites until they reach saturation [41]. In a similar study by Torab-Mostaedi (2013), biosorption of Ni (II) reached equilibrium within the 60 minutes for the initial $\mathrm{Ni}$ (II) concentration of $50 \mathrm{mg} / \mathrm{L}$ at pH 5 and adsorbent dosage of $4 \mathrm{~g} / \mathrm{L}$. After that optimum contact time, Ni (II) uptake capacity of the biomass was insignificantly effected by the extending time [42].

\section{Biosorption Isotherms}

Langmuir and Freundlich isotherm models are the most-used linear models that explain the mechanism of biosorption between the metal ions and biomass. In the study the obtained data were also applied to these two models. Equations of both of the models are:

$$
\frac{C_{e}}{q_{e}}=\frac{1}{\left(q_{\max } K_{L}\right)}+\frac{C_{e}}{q_{\max }}
$$

$$
\ln q_{e}=\ln K_{F}+\frac{1}{n} \ln C_{e}
$$

...where $\mathrm{q}_{\max }$ is the maximum biosorption capacity of biomass $(\mathrm{mg} / \mathrm{g}), \mathrm{q}_{\mathrm{e}}$ is the amount of $\mathrm{Ni}$ (II) ions biosorbed by the per gram of biomass at the equilibrium $(\mathrm{mg} / \mathrm{g})$, $\mathrm{C}_{\mathrm{e}}$ is the equilibrium concentration of $\mathrm{Ni}$ (II) solution $(\mathrm{mg} / \mathrm{L}), \mathrm{K}_{\mathrm{L}}$ is the Langmuir biosorption constant $(\mathrm{L} / \mathrm{g})$ related to the free energy of biosorption, and $\mathrm{K}_{\mathrm{F}}(\mathrm{L} / \mathrm{g})$ and $\mathrm{n}$ (dimensionless) are the Freundlich isotherm constants that are related to the biosorption capacity and biosorption intensity [43].

Figs 6 and 7 show the linear form of Langmuir and Freundlich isotherms obtained by plotting $\mathrm{C}_{\mathrm{e}} / \mathrm{q}_{\mathrm{e}}$ versus $\mathrm{C}_{\mathrm{e}}$ and $\operatorname{lnq}_{\mathrm{e}}$ versus $\ln _{\mathrm{e}}$ for the biosorption of $\mathrm{Ni}$ (II) ions onto

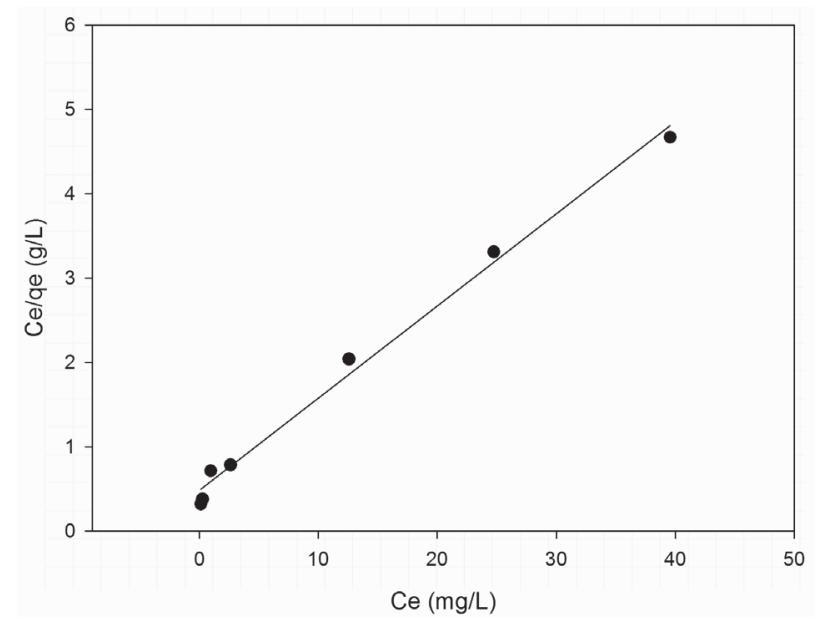

Fig. 6. Langmuir plots for Ni (II) ions biosorption onto $L$. salicaria roots (pH:7, biomass dosage: $6 \mathrm{~g} / \mathrm{L}$, contact time: $40 \mathrm{~min}$.).

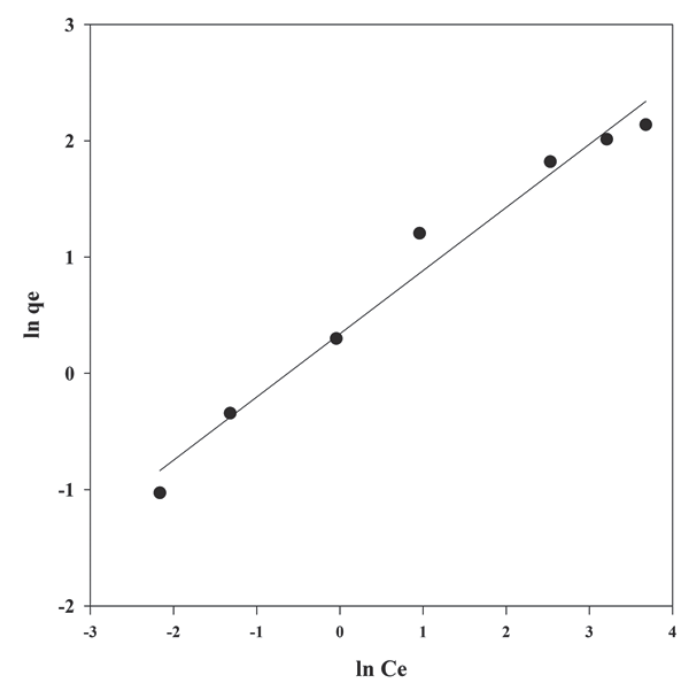

Fig. 7. Freundlich plots for Ni (II) ions biosorption onto $L$. salicaria roots ( $\mathrm{pH}: 7$, biomass dosage: $6 \mathrm{~g} / \mathrm{L}$, contact time: 40 min.). 
Table 1. Isotherm constants for the biosorption of $\mathrm{Ni}$ (II) ions onto L. salicaria roots.

\begin{tabular}{|c|c|c|c|c|c|}
\hline \multicolumn{3}{|c|}{ Langmuir } & \multicolumn{3}{c|}{ Freundlich } \\
\hline $\mathrm{q}_{\max }\left(\mathrm{mg} \mathrm{g}^{-1}\right)$ & $\mathrm{K}_{\mathrm{L}}\left(\mathrm{L} \mathrm{mg}^{-1}\right)$ & $\mathrm{r}^{2}$ & $\mathrm{n}$ & $\mathrm{K}_{\mathrm{F}}\left(\mathrm{Lg}^{-1}\right)$ & $\mathrm{r}^{2}$ \\
\hline 9.1580 & 0.2264 & 0.9923 & 1.8400 & 1.4015 & 0.9772 \\
\hline
\end{tabular}

L. salicaria roots at room temperature, respectively, and isotherm model parameters are listed in Table 1.

The Langmuir isotherm model has one more constant defined as separation factor, $\mathrm{R}_{\mathrm{L}}$, that is used to determine whether the process is favorable or not. It can be calculated by the following equation (Eq. 3):

$$
R_{L}=\frac{1}{\left(1+K_{L} C_{0}\right)}
$$

...where $\mathrm{C}_{0}(\mathrm{mg} / \mathrm{L})$ is the initial $\mathrm{Ni}$ (II) concentration in the solution. The calculated result from Eq.3 for the biosorption of $\mathrm{Ni}$ (II) at room temperature is found to be 0.0423 . The $R_{L}$ constant being in the interval of 0 and 1 indicates that the biosorption of $\mathrm{Ni}$ (II) onto roots of L. salicaria is favorable [29].

All the parameters for the Lanqmuir and Freundlich isotherms are given in Table 1 . When the $\mathrm{r}^{2}$ values are compared in Table 1, it is clearly seen that the Ni (II) adsorption data of biomass as a function of equilibrium concentrations at room temperature were fitted to the Langmiur isotherm equation very well. From the Langmuir model, the monolayer biosorption capacity of L. salicaria biomass was found to be $9.1580 \mathrm{mg} / \mathrm{g}$ for $\mathrm{Ni}$ (II) ions.

\section{Conclusions}

Soil and water contamination with $\mathrm{Ni}$ has become a worldwide problem [21]. Nickel is one of the most important heavy metals that is widely distributed in rivers and lakes of Kütahya. Thus, Ni has been released into the environment from wastewater of ceramic, porcelain, and tile industries in Kütahya [1].

This study investigated phytoremediation and biosorption of Ni (II) by L. salicaria. The data showed that $L$. salicaria was an efficient biomaterial for removal of $\mathrm{Ni}$ (II) from aquatic systems in phytoremediation and biosorption techniques. While $3.7378 \mathrm{mg} / \mathrm{g} \mathrm{Ni}$ (II) was removed by L. salicaria roots at $10 \mathrm{mg} / \mathrm{L} \mathrm{Ni}$ (II) and $\mathrm{pH} 7$ in a phytoremediation study, $9.1580 \mathrm{mg} / \mathrm{g} \mathrm{Ni}$ (II) was removed at $\mathrm{pH} 7$ at a dosage of $6 \mathrm{~g} / \mathrm{L}$ and contact time of $40 \mathrm{~min}$. in a biosorption study. In conclusion, L. salicaria roots are the most effective biomaterial for biosorption and phytoremediation studies for the removal of $\mathrm{Ni}$ (II) from aquatic systems.

\section{References}

1. PULATSÜ S., TOPÇU A. Review of 15 Years of research on sediment heavy metal contents and sediment nutrient release in inland aquatic ecosystems, Turkey. J Water Resource Prot. 7, 85, 2015

2. ABDALLAH M.A.M. Phytoremediation of heavy metals from aqueous solutions by two aquatic macrophytes, Ceratophyllum demersum and Lemna gibba L. Environ. Technol. 33, 1609, 2012.

3. ISLAM M.S., AHMED M.K., RAKNUZZAMAN M., HABIBULLAH -AL- MAMUN M., ISLAM M.K. Heavy metal pollution in surface water and sediment: A preliminary assessment of an urban river in a developing country. Ecological Indicators. 48, 282, 2015.

4. BORAN M., ALTINOK I. A Review of heavy metals in water, sediment and living organisms in the Black Sea. Turk. J. Fish. Aquat. Sci. 10, 565, 2010.

5. GUPTA A., JOIA J., SOOD A., SOOD R., SIDHU C., KAUR G. Microbes as potential tool for remediation of heavy metals: A Review. J. Microb. Biochem. Techno. 8 (4), 364, 2016.

6. TCHOUNWOU P.B., YEDJOU C.G., PATLOLLA A.K., SUTTON D.J. Heavy metals toxicity and the environment. EXS. doi: 10.1007/978-3-7643-8340-4 6, 2014.

7. SZYCZEWSKI P., SIEPAK J., NIEDZIELSKI P., SOBCZYŃSKI T. Research on heavy metals in Poland. Polish J. of Environ. Stud. 18 (5), 755, 2009.

8. SARI A., TUZEN M., ULUÖZLÜ Ö.D., SOYLAK M. Biosorption of $\mathrm{Pb}$ (II) and $\mathrm{Ni}$ (II) from aqueous solution by lichen (Cladonia furcata) biomass. Biochem. Eng. J. 37, 151, 2007.

9. GUNATILAKE S.K. Methods of removing heavy metals from industrial wastewater. J. Multidiscip. Eng. Sci. Stud. $1(1), 12,2015$.

10. GHOSH M., SINGH S.P. A review on phytoremediation of heavy metals and utilization of it's by products. As. J. Energy. Env. 6 (4), 214, 2005.

11. DIXIT R., WASIULLAH, MALAVIYA D., PANDIYAN K., SINGH U.B., SAHU A., SHUKLA R., SINGH B.P., RAI J.P., SHARMA P. K., LADE H., PAUL D. Bioremediation of heavy metals from soil and aquatic environment: An overview of principles and criteria of fundamental processes. Sustainability. 7, 2189, 2015.

12. SHARMA S., RANA S., THAKKAR A., BALDI A., MURTHY R.S.R., SHARMA R.K. Physical, Chemical and phytoremediation technique for removal of heavy metals. Journal of Heavy Metal Toxicity and Diseases. 1 (2), 1, 2016.

13. CHOJNACKA K. Biosorption and bioaccumulation-the prospects for practical applications. Environ. Int. 36, 299, 2010.

14. ZABOCHNICKA-ŚWIĄTEK M., KRZYWONOS M. Potentials of biosorption and bioaccumulation processes for 
heavy metal removal. Pol. J. Environ. Stud. 23, 551, 2014.

15. TANGAHU B.V., ABDULLAH S.R.S., BASRI H., IDRIS M., ANUAR N., MUKHLISIN M.A. Review on heavy metals (As, $\mathrm{Pb}$, and $\mathrm{Hg}$ ) uptake by plants through phytoremediation. Int. J. Chem. Eng. Article ID 939161, 1, 2011.

16. DAVIS P.H. Flora of Turkey and East Egean Islands. Publisher: Edinburg University Press, London, 1965-1988.

17. TURE C., BINGOLN.A., MIDDLETON B. Characterization of the habitat of Lythrum salicaria L. in floodplain forests in western Turkey-Effects on stem height and seed production. Wetlands 24, 711, 2004.

18. PIWOWARSKI J.P., GRANICA S., KISS A.K. Lythrum salicaria L.-Underestimated medicinal plant from European traditional medicine. A review. J. Ethnopharmacol. 170, 226, 2015.

19. RAUHA J.P., REMES S., HEINONEN M., HOPIA A., KÄHKÖNEN M., KUJALA T., PIHLAJAK., VUORELAH., VUORELA P. Antimicrobial effects of Finnish plant extracts containing flavonoids and other phenolic compounds. Int. J. Food. Microbiol. 56, 3, 2000.

20. HUMADI S.S., ISTUDOR V. Lythrum salicaria (purple loosestrife). Medicinal use, extraction and identification of its total phenolic compounds. Farmica 57 (2), 192, 2009.

21. CHEN C., HUANG D., LIU J. Functions and toxicity of nickel in plants: Recent advances and future prospects. Clean 37, 304, 2009.

22. CEMPEL M., NIKEL G. Nickel: A Review of Its Sources and Environmental Toxicology. Polish J. of Environ. Stud. $15(3), 375,2006$.

23. ZAMBELLI B., UVERSKY V.N., CIURLI S. Nickel impact on human health: An intrinsic disorder perspective. Biochimica et Biophysica Acta. 1864, 1714, 2016.

24. MASOUMI F., KHADIVINIA E., ALIDOUSTA L., MANSOURINEJAD Z., SHAHRYARI S., SAFAEI M., MOUSAVI A., SALMANIAN A., ZAHIRI H. S., VALI H. Nickel and lead biosorption by Curtobacterium sp. FM01, an indigenous bacterium isolated from farmland soils of northeast Iran. J. Environ. Chem. Eng. 4, 950, 2016.

25. KACAR B., INAL A. Bitki Analizleri, $1^{\text {st }}$ ed.; Nobel Yayın Dağıtım Ltd. Şti.: Ankara, Türkiye, 157, 2008 [In Turkish].

26. JMP SAS. SAS Institute Inc. USA, 1995.

27. SINGH K., PANDEY S.N. Effect of nickel-stresses on uptake, pigments and antioxidative responses of water lettuce, Pistia stratiotes L. J. Environ. Biol. 32, 391, 2011.

28. CHAMI Z.A., AMER N., BITAR L.A., CAVOSKI I. Potential use of Sorghum bicolor and Carthamus tinctorius in phytoremediation of nickel, lead and zinc. Int. J. Environ. Sci. Technol. 12, 3957, 2015.

29. KAUR L., GADGIL K., SHARMA S. Role of $\mathrm{pH}$ in the accumulation of lead and nickel by common duckweed (Lemna minor). Int. J. Bioassays. 12, 191, 2012.

30. KUKIER U., PETERS C.A., CHANEY R. L., ANGLE J. S., ROSEBERG R. J. The effect of $\mathrm{pH}$ on metal accumulation in two Alyssum species. J. Environ. Qual. 33 (6), 2090, 2004.
31. FUENTES I.I., SPADAS-GIL F., TALAVERA-MAY C., FUENTES G., SANTAMARÍA J.M. Capacity of the aquatic fern (Salvinia minima Baker) to accumulate high concentrations of nickel in its tissues, and its effect on plant physiological processes. Aquatic Toxicology. 155, 142, 2014.

32. YUSUF M., FARIDUDDIN Q., HAYAT S., AHMAD A. Nickel: An Overview of Uptake, Essentiality and Toxicity in Plants. Bull. Environ. Contam. Toxicol. 86, 1, 2011.

33. VAJPAYEE P., RAI U.N., ALI M.B., TRIPATHI R.D., YADAV V., SINHA S., SINGH S.N. ChromiumInduced changes in Vallisneria spiralis L. and its role in phytoremedation of tannery effluents. Bull. Environ. Toxicol., 67, 246, 2001.

34. ABDIA O., KAZEMI M. A review study of biosorption of heavy metals and comparison between different biosorbents. J. Mater. Environ. Sci. 6 (5), 1386, 2015.

35. ÖZCAN A.S., ÖZCAN A., TUNALI S., AKAR T., KIRAN I., GEDIKBEY T. Adsorption potential of lead (II) ions from aqueous solutions onto Capsicum annuиm seeds. Separ. Sci. Technol. 42, 137, 2007.

36. UCUN H., BAYHAN Y. K., KAYA Y., CAKICI A., ALGUR O. F. Biosorption of lead (II) from aqueous solution by cone biomass of Pinus sylvestris. Desalination 154 (3), 233, 2003.

37. AKAR T., KAYNAK Z., ULUSOY S., YUVACI D., OZSARI G., AKAR S.T. Enhanced Biosorption of nickel (II) ions by silica-gel-immobilized waste biomass: Biosorption characteristics in batch and dynamic flow mode. J. Hazard. Mater.163, 1134, 2009.

38. HANIF M.A., NADEEM R., BHATTI H. N., AHMAD N. R., ANSARI T. M. Ni(II) biosorption by Cassia fistula (Golden Shower) biomass. J. Hazard. Mater. B139 (2), 345, 2007.

39. YUVARAJA G., KRISHNAIAH N., SUBBAIAH M.V., KRISHNAIAH A. Biosorption of $\mathrm{Pb}$ (II) from aqueous solution by Solanum melongena leaf powder as a lowcost biosorbent prepared from agriculture waste. Colloid. Surface. B114, 75, 2014.

40. REDDY D.H.K., HARINATH Y., SESHAIAH K., REDDY A.V.R. Biosorption of $\mathrm{Pb}$ (II) from aqueous solutions using chemically modified Moringa oleifera tree leaves. Chem. Eng. J. 162, 626, 2010.

41. FAWZY M., NASR M., ADEL S., NAGY H., HELMI S. Environmental approach and artificial intelligence for $\mathrm{Ni}$ (II) and Cd (II) biosorption from aqueous solution using Typha domingensis biomass. Ecol. Eng. 95, 743, 2016.

42. TORAB-MOSTAEDI M., ASADOLLAHZADEH M., HEMATTI A., KHOSRAVI A. Equilibrium, kinetic, and thermodynamic studies for biosorption of cadmium and nickel on grapefruit peel. J. Taiwan Inst. Chem. E. 44, 295, 2013.

43. GUNDOGDU A., OZDES D., DURAN C., BULUT V.N., SOYLAK M., SENTURK H.B. Biosorption of Pb (II) ions from aqueous solution by pine bark (Pinus brutia Ten.). Chem. Eng. J. 153, 62, 2009. 